\title{
A BRIEF OVERVIEW OF BIBLE TRANSLATION IN SOUTH AFRICA
}

\author{
E.A. Hermanson ${ }^{1}$
}

\begin{abstract}
Christianity came to South Africa in 1652, but missionary outreach to the indigenous population only began in earnest in the 19th century. The first formal-equivalent Bible translations were done by missionaries in the latter part of the 19th and early 20th century. Since the mid-1960s the Bible Society has facilitated functional-equivalent translations by teams of mother-tongue translators, and is currently completing the Old Testament in Southern Ndebele, the only South African official language without a complete Bible. Advances in translation theory present new challenges in translating the Bible to communicate in the contemporary linguistic situation.
\end{abstract}

\section{INTRODUCTION}

On 6 April 1652, Jan van Riebeeck landed at the Cape of Good Hope, and established a European settlement at the southern tip of Africa. Some attempts were made to Christianise the indigenous people who came into contact with the settlers, or who worked for them. This often meant no more than that slaves, some of whom came from countries such as Malaysia and the Dutch East Indies, took part in the family devotions of their masters, which were conducted in Dutch.

It was only in the early 19th century that a concerted effort was made to reach out to the indigenous people with the establishment of work by various British, American, German, French and Swiss missionary societies. At the same time as this new missionary fervour, which included the study and committing to writing of African languages, came the establishment of the British and Foreign Bible Society (BFBS) on 7 March 1804, and its auxiliary, the South African Bible Society in Cape Town on 23 August 1820. The

1 Dr. Eric A. Hermanson, Assistant General Secretary: Text Processing, Bible Society of South Africa; and Research Associate, Department of Old Testament Studies, Faculty of Theology, University of Pretoria. Dr. Hermanson participates as associate in the research project "Bible Translation", directed by Prof. Andries P. B. Breytenbach, Head of the Department of Old Testament Studies, Faculty of Theology, University of Pretoria. E-mail: hermanson@biblesociety.co.za 
Bible Society of South Africa began functioning as an autonomous body, independent of the BFBS on 1 November 1965, and with this came a new impetus for Bible translation.

In South Africa, two clearly defined periods of Bible translation, corresponding to the last two postulated by Orlinsky and Bratcher (1991), can be distinguished: 1) The Missionary Society Period, with formal-equivalent translations being made by missionaries, sometimes with Bible Society help towards the publishing costs, and 2) The Bible Society Period, with dynamic-/functional-equivalent translations being made by interdenominational translation teams, under the guidance and supervision of the Bible Society.

\section{THE MISSIONARY PERIOD}

Today, in addition to English and Afrikaans, South Africa officially recognises nine African languages of the Bantu group, each with a number of dialects. Four are Nguni, viz. Zulu, Xhosa, Swati and Southern Ndebele; three are Sotho, viz. Southern Sotho, Northern Sotho and Tswana; and then Tsonga and Venda. With the exception of Nama, spoken mostly in Namibia now, the Khoi languages have become extinct, while some San languages are still spoken in Namibia, Botswana and Angola.

As in other parts of Africa, the history of the expansion of Christianity in South Africa began with different missionary societies working among different tribes. Early Bible translation was undertaken by an individual or a group of missionaries, usually from the same society. In some cases the translations were published by the mission itself, either on a mission press, or a commercial press in South Africa, or on a press in the mission's home country. In other cases one of the Bible Societies, such as the BFBS, the American Bible Society (ABS) and the French Bible Society made grants of paper and/or financial aid for printing and binding. As an indication of the dedication of missionaries in Africa to Bible translation, Doke (1958:82) pointed out that up to 1938 nearly one quarter of the world's New Testaments, one seventh of the world's complete Bibles, and nearly one sixth of Scripture portions, were translations into languages classified as Bantu Languages.

In preparation for their work, many missionaries studied Hebrew, Greek and Latin. Translation theory was not well developed and so when they came to translate the Scriptures they did so with formal equivalence, in the same way as they had been taught to translate the Classics, matching word for word and structure for structure wherever possible. It must be noted, however, that some translators made an attempt towards what would have been regarded at the time to be a more idiomatic rather than literal 
translation, involving mother-tongue speakers and using something of the genius of the language into which they were translating. They used the Hebrew and Greek texts available at the time, together with the translations in their own languages as source texts. Sometimes the influence of translations such as the English AV can be detected. On the other hand, however, when the Xhosa Bible, revised by the Rev. J. W. Appleyard was published by the BFBS in 1864, missionaries of the Scottish and German societies published a pamphlet condemning his version. Doke (1958:86-7) comments that "most of his critics' arguments were based on translating from the English Authorised Version." But, he continues:

Appleyard may have erred in his too close an adherence to the Greek and Hebrew, sometimes straining Xhosa idiom. He was certainly ahead of his day in principles of Bible translation. His critics, on the other hand, were prepared to take liberties in translating rather than to intrude any awkward phrases.

Judging a translation against one in another language, rather than against the original is certainly misguided. However, one would question whether one who adhered closely to the Greek and Hebrew and so sometimes strained Xhosa idiom was indeed ahead of his time in the principles of Bible translation!

During this period, formal-equivalent translations of the Bible were made in Tswana (London Missionary Society) Moffat, 1857; Wookey 1908; Central Tswana (Berlin, Hermannsburg and Dutch Reformed) 1970; Xhosa 1859 (Wesleyan Missionary Society) Appleyard 1864; Revised 1899; 1942; 1975; Southern Sotho 1881 (printed)/1883 (distributed) (Paris Evangelical Mission 1883), Revised 1899, 1909; 1961; 1976; Zulu (American Zulu Mission [ABS]) 1883; Revised 1893 (still in print); new translation 1924 (discontinued); (Hermannsburg Mission) 1924; (Natal Missionary Conference [BFBS]) 1959; Tsonga (Swiss Mission) 1906, Revised 1929; Northern Sotho (Berlin Mission) 1904, 1951; Venda (Berlin Mission) 1936; Afrikaans (Plenary Committee Dutch Reformed Church [BFBS]) 1933, Revised 1953.

Portions of Scripture in Afrikaans were published in 1878, 1889 and 1893 , but it was a lecture by Dr. B. B. Keet on 21 August 1914 in Stellenbosch which started a concerted effort to "Afrikaansify" the Dutch State Bible. On 16 May 1916, a resolution was passed by the Free State Synod of the Dutch Reformed Church (N.G. Kerk), in collaboration with the Nederduitsch Hervormde Kerk and Gereformeerde Kerk to translate the Bible into Afrikaans. The first attempt to translate the Gospels and Psalms from the State Bible met with such adverse criticism when it appeared in 1922, 
that it was decided to start a completely new translation from the original languages. The first consignment of the new Bibles arrived from England on 1 June 1933, and it was officially taken into use by the three churches on 27 August 1933. The final translators were Drs. J. D. Kestell, E. E. van Rooyen, B. B. Keet (N.G. Kerk), H. C. M. Fourie (Ned. Herv. Kerk) and J. D. du Toit (Geref. Kerk). A revision of this Bible, under the editorship of Drs. J. D. du Toit and B. B. Keet was published in 1953.

\section{THE BIBLE SOCIETY PERIOD}

The Bible Society of South Africa became an autonomous body on 1 November 1965, at the time when Dr. E. A. Nida was developing his theory of dynamic-equivalent translation in publications such as Towards a science of translating (1964) and The theory and practice of translation (1969). In fact, this latter publication includes: "A typical set of principles for translation ... worked out at a translators' seminar held in Turfloop, South Africa, in July 1967" (1969:181ff.). The seminar from 8-26 July 1967, was attended by more than 100 people representing 17 translation projects. Lectures were given by various people including Dr. E. A. Nida, Prof. A. S. Herbert and the Rev. H. K. Moulton. Because of the amount of translation and revision being done, the Rev. J. C. C. Pauw was appointed Secretary for Translations commencing from 1 April 1967, and the Rev. (later Dr.) J. L. Reyneke as Translations Advisor from January 1969. Further seminars for all the translation teams were held from 8-18 January 1979, led by Dr. Eugene Nida and Dr. Jan de Waard; from 12-22 January 1982 on manuscript preparation, and from 24 June to 6 July 1985, once again led by Dr. Nida and Prof. J. P. Louw. During this period, portions of Scripture were translated and published for the first time in languages of South Africa such as Swati and Southern Ndebele.

Existing revision and translation committees were introduced to the theory of dynamic equivalence, and where the churches and missions felt the need for new translations, training seminars were held to give practice in the application of the theory and to select competent translators who were acceptable to the churches who would use the Bible once it was published, and the Bible Society.

The pattern has been to select an Editorial Committee, consisting of a co-ordinator who has had theological training including Hebrew and Greek and who has at least a thorough working knowledge of the indigenous language, and two mother-tongue speakers, who do not necessarily have any knowledge of the original languages, as translators. This committee makes 
a draft translation based on existing translations such as the RSV, GNB, NIV, NAV and Gute Nachricht, after each passage has been examined and explained from either the BHS or the GNT in a session with the co-ordinator. Use is made of commentaries, especially the Translators' Handbooks and other helps, published by the United Bible Societies. The translators are free to ask assistance from Old and New Testament scholars and African linguists. Once the Editorial Committee is satisfied with their draft, it is distributed to a Review Committee for comment. This committee is an active interdenominational group of interested people consisting of mother-tongue linguists, clergy, schoolteachers, authors and others, such as missionaries, who have knowledge of the language and interest in the translation. In order to ensure the greatest possible involvement by any who have an interest in the translation, the draft manuscripts may also be sent to others who request them, but who may not necessarily respond with comments. These are known as the Consultative Committee. The Editorial Committee considers all comments submitted, and prepares and distributes a second draft. Once comments have been received on this, the Review Committee meets with the Editorial Committee, and usually the Bible Society's Translation Officer, to finalise the manuscript ready for publication. At this meeting, the text is often read aloud, so that the flow of the language can be heard as well as seen. The finalised text is then submitted to the Bible Society for publication. With the introduction of computer technology, Computer Assisted Text Processing (CATP) programs, such as Translator's Workplace and Paratext, have been introduced which enable the translators to do the necessary mechanical checks on their translations more efficiently.

The Afrikaans Bible translation project operated differently in that there was a larger Editorial Committee, consisting of academics from the three sister Dutch Reformed Churches, all of whom were proficient in either Greek or Hebrew and could therefore translate from the original text. Drafts were considered by a larger committee, and after publication a committee consisting of Profs. E. P. Groenewald, P. A. Verhoef, J. P. Oberholzer, J. L. Helberg, G. M. M. Pelser, J. C. Coetzee, C. E. Pretorius, J. P. Louw, and W. Kempen met regularly for a number of years to consider suggestions submitted by readers, and to reformulate the translation of certain key words and verses.

Prior to the independence of Namibia and the Bible Society of Namibia becoming autonomous, the Bible Society of South Africa was responsible for overseeing a number of translation projects there as well. Some of these languages had not previously had any Scripture translations published prior to this. At one time the Bible Society of South Africa was responsible for translation projects in over twenty Southern African languages. 
Dynamic-/functional-equivalent translations in South African official languages which have been published by the Bible Society of South Africa during this period include: Afrikaans Bible (1983); Zulu New Testament and Psalms (1986); Southern Ndebele New Testament and Selection of Psalms (1986 — First translation); Southern Sotho Bible in two orthographies - that of Lesotho and of South Africa (1989); Tsonga Bible (1989); Xhosa Bible (1996); Swati Bible (1996 — first translation); Venda Bible (1998); Northern Sotho (2000).

In January 1997 a start was made with translating the Bible into Afrikaans for the Deaf. Although a Bible for the Deaf has been published in American English, this is the first time that such a limited vocabulary translation has been attempted by a Bible Society. The translation committee, under the chairmanship of Prof. J. P. Oberholzer, includes Dr. Rocco Hough, minister of the De la Bat Deaf congregation, Miss Elmine Roux, a retired teacher of the Deaf, and Mr. Ernst Kleinschmidt, a prominent member of the Deaf community who was received his M.A. in General Linguistics in 1997 for a dissertation on Sign Language. Assistance is also being given by Profs. D. Francois Tolmie and Hermie C. van Zyl of the University of the Free State and Profs. Christo H. J. van der Merwe and H. C. Bernard Combrink of Stellenbosch University.

People often ask why the Deaf need their own translation, seeing that they can read. The problem is that the majority has a very small vocabulary and find figurative language very difficult to understand. For example: The Afrikaans word for "create" is "skep", but the Deaf are more familiar with another meaning of the word "skep", viz. "scoop" or "ladle". So, it is necessary simply to say "In die begin het God die hemele en die aarde gemaak" (In the beginning God made the heavens and the earth) than "In die begin het God die hemele en die aarde geskep" (In the beginning God created the heavens and the earth) as in the 1983 translation. Similarly, if one says "Die Israeliete vier fees" (The Israelites celebrate a feast), the Deaf understand the word "vier" as the numeral "four" and become confused. It is better to say simply "Die Israeliete hou fees" (The Israelites hold a feast). Passive sentence constructions are also confusing and care needs to be taken to change them into active sentences. So, instead of saying, "The dog was hit by the man", one would say, "The man hit the dog".

The Committee published a trial publication of Genesis and Mark in 1998 and a volume containing the Minor Prophets and Daniel on 10 September 2000. The four Gospels were published on 28 July 2002.

Translation of the Old Testament into Southern Ndebele, the only official language of South Africa which as yet does not have a complete Bible 
but only the New Testament and a Selection of Psalms published in 1986, was begun at the University of Pretoria in January 1999. Prof A. P. B. Breytenbach is the exegete with Pastor David Mahlangu and Mr Peter Mabena, previously a translator with the Mpumalanga Government, as translators. On 22 July 2000 the first fruits of their labours were published in an attractive booklet called Umusa kaZimu ungowabo boke (God's grace is for all), containing the books of Ruth and Jonah.

Another vital contribution by the Bible Society of South Africa to Bible translation has been the publishing of a series of monographs and also the joint publication with the United Bible Societies of the Greek-English lexicon of the New Testament based on semantic domains. (See Appendix 2.) Work was begun some years ago on the preparation of a similar publication on Biblical Hebrew, and is making slow progress.

\section{THE WAY AHEAD}

Research done on behalf of the Bible Society by the Institute for Missiological and Ecumenical Research at Pretoria University, revealed that between 12 and 20 million people in South Africa are functionally illiterate and therefore do not have access to the printed Word. In February 2001 a workshop run by Dr. Viggo Søgaard the United Bible Societies' Media Consultant, was held to help plan our strategy for the provision of Audio Scriptures to meet their needs. It was decided to begin by focussing on Zulu and the Rev. Josiah Mazibuko, Regional Secretary of the Esikhawini office, attended the first course of the Africa Institute of Christian Communication, run by Dr. Søgaard in Kempton Park during July 2001.

In August 2001, a most successful Symposium on Bible Translation, to which a number of international scholars were invited, was held in Kempton Park. It was designed to up-date Bible Society personnel and local academics on the advances in the field of translation theory as a step towards the possible translation of a Bible in contemporary Afrikaans, which has been requested by some churches. Market research into the need for such a translation was also undertaken in collaboration with the Centre for Interdisciplinary Studies at the University of Stellenbosch.

There may also be need to begin a new translation of the Old Testament in Zulu, the largest language group in South Africa, and of the complete Bible in Tswana, as neither language has a functional-equivalent translation.

When one realises that there is almost no theological literature in any of the African languages, the need for well-written Study Bibles, becomes apparent. These cannot simply be translations of existing publications, but 
must be written in the language and culture for which they are intended. Projects are underway further up Africa in Chewa of Malawi and Zambia and Swahili in East and Central Africa. Already there has been a request for such a Bible in Swati, a language which received the first complete Bible only in 1997.

Some of the smaller language groups such as the Northern Ndebele of the Potgietersrust and Zebediela area, and the Lovedu of the Duiwelskloof area, have begun agitating through the Pan South African Language Board (PANSALB) for the official recognition of their languages by the government, and some have requested the Bible in their own language. Much wisdom will be required to know how to handle such requests from communities which until now have used translations in cognate languages.

The Bible Society of South Africa continues to look to the Lord for guidance that He will lead us that we will not be led astray, but will be sensitive to the way $\mathrm{He}$ wants us to continue fulfilling the mission $\mathrm{He}$ has given us - to provide the Word of God in the language of the people, in an appropriate format, and at an affordable price.

\section{APPENDIX 1}

Early translations in South African languages

1. Tswana

The earliest published book of the Bible was the translation of Luke into the Tlhaping dialect of Tswana by Robert Moffat of the London Missionary Society in 1830. In 1840, the BFBS published his translation of the New Testament, the first consignment of 500 of which were brought out by David Livingstone, later to become his son-in-law, on his first voyage to Africa. The following year, they published the New Testament and Psalms. Returning in 1843, after four years in England, Moffat tackled the rest of the Old Testament. From 1847, this was printed in sections on a hand press at Kuruman on paper supplied by the BFBS, until the Bible was completed in 1857.

A number of revisions were made of this Bible until the one, by A. J. Wookey, now in general use in Botswana was published in 1908. An edition is still published in the original orthography, while a light revision in 
the current official orthography was published by the Bible Society of South Africa in 1992.

In 1970, the Bible Society of South Africa published a new translation of the New Testament by the Rev. A. Sandilands of the London Missionary Society. This is no longer in print.

Also in 1970, the Bible Society of South Africa published a new translation by a committee of representatives from the Hermannsburg, Berlin and Dutch Reformed Church Missions. As the vocabulary used is that of the Hurutse, Kwena and Kgatla dialects, it was referred to as Central Tswana. The fact that this Bible was not only translated by representatives of missions working in what was the Transvaal, but was also published in the orthography used in schools in South Africa has contributed to its being in more general use in South Africa than the older translation.

\section{Xhosa}

The first published Xhosa translation was Luke by the Wesleyans, William Boyce and Barnabas Shaw in 1833. A number of missionaries, including $\mathrm{H}$. H. Dugmore, W. J. Davis, C. W. Posselt, J. L. Döhne and J. C. Warner, contributed to the New Testament, printed at Fort Peddie and Newton Dale in 1846.

Missionaries, led by J. W. Appleyard, continued translating the Old Testament and books were published separately as they were completed at the Wesleyan Missionary Press at Mount Coke and King William's Town in 1859. Appleyard revised the New Testament and the complete Bible was published by the BFBS in one volume in 1864 .

A version of the Bible revised by a committee appeared in 1899 and this has undergone various further revisions.

\section{Southern Sotho}

The Société des Missions Evangéliques de Paris (Paris Evangelical Mission) started work at Morija, Lesotho, during 1833-34. The first Gospels in Southern Sotho, Mark, translated by E. Casalis, and John, translated by S. Rolland, were published in 1839. The translation of the New Testament was completed by 1843 , but because of various setbacks, it was printed at the mission press at Beerseba, near Smithfield, and published only in 1855 (Schutte 1971:310-311). The complete Bible was published in France by the BFBS in 1881, but because of the Basuto War, it reached the people only in September 1883 (Smit 1970:210f.)

A revised version of the Bible was published in 1899, a new edition in a revised orthography in 1909, and a further revision in 1942. 
4. Zulu

The story of the translation of the Bible into Zulu is not one of unanimity among the missions (Doke 1958:89).

\subsection{American Zulu Mission}

Missionaries of the American Zulu Mission of the American Board of Commissioners for Foreign Missions, arrived in Port Natal (now Durban) in December 1835. The first Gospel, translated by George Champion and revised by Newton Adams, was published in Pietermaritzburg in 1848. The New Testament was published at the missionary press at Esidumbini $(80 \mathrm{~km}$ south of Durban) in 1865, with funds from the ABS for the printing and a grant from the Durban Auxiliary of the BFBS to cover the binding. The first complete Bible was published in New York by the ABS in 1883.

A revised edition of the Bible was published in 1893, and a facsimile of this edition is still being published today.

A further revision was undertaken under the supervision of the Rev. J. Dexter Taylor and the New Testament was published by the ABS in 1917 and the Bible in 1924. It would appear that these versions were not well accepted and publication was discontinued.

\subsection{Bishop J. W. Colenso}

The Anglican Bishop of Natal, who was a controversial theological figure, published translations of various books of the Bible of his own, culminating in the publication of the New Testament, probably at the end of 1876 (Hermanson 1995:145).

\subsection{Bishop Henry Callaway}

Bishop Callaway first worked under Colenso, but later separated from him. He was "troubled with the Bishop's Scripture translations" (Benham 1896:115) and did extensive translation and publication himself with grants from the SPCK. Doke considered his translations to be extremely good (Doke 1958:89).

\subsection{The Hermannsburg Mission}

In reaction to the revision of the New Testament and Bible published by the ABS in 1917 and 1924, the Hermannsburg Mission published its own translation of each at Moorleigh, near Estcourt in 1924.

\subsection{Roman Catholic Translation}

The Roman Catholic Mission at Mariannhill, published a New Testament, translated under the leadership of Fr. Rafael Studerus OSB, in 1955. 


\subsection{Sarndal Translation}

The Natal Missionary Conference resolved in 1944 that a new translation should be made of the whole Bible, and the Bible currently in popular use was translated by a committee under the leadership of Dean O. Sarndal and first published by the BFBS in 1959 (Smit 1970:215f.).

\section{Tsonga}

The Mission Remande or Swiss Mission began work among the Tsonga in 1875. The New Testament was published at Lausanne by the Mission in 1894, while the complete Bible was published in 1906. A revised version of the New Testament was published in 1917, and the Bible in 1929.

\section{Northern Sotho}

The Berlin Missionary Society started work among the Northern Sotho in the early 1860's, and the New Testament, translated by Pastor J. F. C. Knothe was published in London by the BFBS in 1890, while the Bible was published in Berlin by the Berlin Missionary Society in 1904.

A committee under the chairmanship of Dr. P. E. Schwellnus produced a complete revision of the New Testament which was published by the BFBS in Johannesburg in 1943, and of the Bible, sub-edited by the Rev. J. Baumbach, which was published by the BFBS in London in 1951.

\section{Venda}

Translation of the Gospels and Acts, by Dr. P. E. Schwellnus, were published by the BFBS in London in 1920, the New Testament was published in 1925, and the complete Bible in 1936.

\section{Afrikaans}

From 1872 onwards certain protagonists advocated that Afrikaans should be used as a written language (Smit 1970:225ff.). Translations of various books of the Bible were made and published, but it was not until 1917 that a request by the Dutch Reformed Churches of the Orange Free State and Transvaal led the BFBS to decide "to undertake the cost of producing a version of the Scriptures in Afrikaans or Cape Dutch". The first tentative translation was a complete failure as it was too much "a translation of a translation". In July 1923 Dr. J. D. du Toit and Dr. B. B. Keet were selected as full-time, and Drs. J. D. Kestell, H. C. M. Fourie and E. E. van Rooyen as part-time translators, to translate from the original with preference for the Textus Receptus. This Bible was published by the BFBS and arrived in Cape Town on 1 June 1933. 


\section{APPENDIX 2}

List of Scholarly Publications Published by the Bible Society of South Africa

LouW J P (ed.)

1985. Lexicography and translation. With special reference to Bible translation. Cape Town: Bible Society of South Africa.

Nida E A, Louw J P, Snyman A H \& Cronje J v W

1983. Style and discourse. With special reference to the text of the Greek New Testament.

Cape Town: Bible Society of South Africa.

NIDA E A

1984. Signs, sense, translation. Cape Town: Bible Society of South Africa.

NidA E A \& LOUw J P

1988. Greek-English lexicon of the New Testament based on semantic domains. Cape Town: Bible Society of South Africa.

\section{WENDLAND E}

1985. Language, society and Bible Translation. With special reference to the style and structure of segments of direct speech in the Scriptures. Cape Town: Bible Society of South Africa.

WENDLAND E \& LOUW J P

1993. Graphic design and Bible reading. Cape Town: Bible Society of South Africa.

\section{APPENDIX 3}

Summary, by geographical area and type of publication, of the number of different languages and dialects in which publication of at least one book of the Bible had been registered as of 31 December 2001. (United Bible Societies World Report 367, March 2002).

\begin{tabular}{|l|c|c|c|c|}
\hline Continent or Region & Portions & Testaments & Bibles & Total \\
\hline Africa & 213 & 279 & 149 & 641 \\
\hline Asia & 223 & 228 & 119 & 570 \\
\hline $\begin{array}{l}\text { Australia/New Zealand/ } \\
\text { Pacific Islands }\end{array}$ & 168 & 204 & 33 & 405 \\
\hline Europe & 110 & 31 & 62 & 203 \\
\hline North America & 40 & 26 & 7 & 73 \\
\hline $\begin{array}{l}\text { Caribbean/Central America/ } \\
\text { Mexico/South America }\end{array}$ & 127 & 244 & 21 & 392 \\
\hline Constructed Languages & 2 & 0 & 1 & 3 \\
\hline Total & 883 & 1,012 & 392 & 2,287 \\
\hline
\end{tabular}


Hermanson

A brief overview of Bible translation in South Africa

\section{BIBLIOGRAPHY}

\section{BENHAM M S}

1896. Henry Callaway. First bishop of Kaffraria. London: Macmillan.

\section{DOKE C M}

1958. Scripture translation into Bantu Languages. African Studies 17:2.

HERMANSON E A

1995. Metaphor in Zulu: problems in the translation of Biblical metaphor in the Book of Amos. Unpublished D. Litt. thesis. University of Stellenbosch.

\section{ORLINSKY H M \& BRATCHER R G}

1991. A bistory of Bible translation and the North American contribution. Atlanta, GA: Scholars Press.

\section{SCHUTTE P J}

1971. Sendingdrukperse in Suid-Afrika 1800-1875. Potchefstroom: Pro Rege.

\section{SMIT A P}

1970. God made it grow - History of the Bible Society Movement in Southern Africa 1820-1970. Cape Town: Bible Society of South Africa.

Keywords

Bible translation

South African languages

Missionary period

Bible Society period

Formal-equivalent translations

Dynamic-/functional-equivalent translations

Bible for the Deaf 